\title{
Does automation or discretion drive money supply in Bulgaria?
}

\section{Será que a automação ou a discrição direcionam a oferta monetária na Bulgária?}

\author{
Ivan Todorov \\ Faculty of Economics, Department of Finance and Accounting, Bulgaria \\ ivank.todorov@swu.bg \\ Stoyan Tanchev \\ Faculty of Economics, Department of Finance and Accounting, Bulgaria \\ saneto@swu.bg \\ Peter Yurukov \\ Faculty of Economics, Department of Finance and Accounting, Bulgaria \\ petaryurukovofficial@gmail.com
}

\begin{abstract}
The options for monetary discretion under the Bulgarian currency board arrangement (CBA) were analysed. A vector autoregression (VAR) was employed to identify the determinants of money supply in Bulgaria for the period 1998-2018. The results of the study imply that the movements of money supply in Bulgaria do not automatically follow the dynamics of the balance of payments but are affected in a discretionary way by the changes in the government deposit in the Issue Department of the Bulgarian National Bank (BNB). It may be inferred that money supply in Bulgaria under a CBA is more discretion-driven than automatically determined.
\end{abstract}

Keywords: Bulgaria; currency board arrangement; money supply; automation; discretion.

\section{Resumo}

Neste artigo analisam-se as opções de discrição monetária sob o acordo do Conselho Monetário da Bulgária (CMB). Nesse sentido, aplicou-se uma autorregressão vetorial (VAR) para identificar os determinantes da oferta monetária na Bulgária, no período compreendido entre 1998 e 2018. Os resultados sugerem que os movimentos da oferta monetária na Bulgária não seguem automaticamente a dinâmica da balança de pagamentos, mas são afetados de maneira discricionária pelas alterações dos depósitos do governo no Departamento de Emissão do Banco Nacional da Bulgária (BNB). Pode-se inferir que a oferta monetária na Bulgária sob uma CMB é mais orientada pela discrição do que determinada automaticamente.

Palavras-chave: Bulgária; conselho monetário; oferta monetária; automação; discrição. 


\section{Introduction}

The main difference between a central bank (CB) and a currency board arrangement (CBA) is the existence of an automatic mechanism for a relatively rapid correction of economic imbalances under a CBA. Despite the similarities, the automated mechanisms of the Gold Standard (GS) and the CBA are not identical for several reasons. First, the Gold Standard is an international monetary regime and its automatic adjustment mechanism operates simultaneously in all countries, whereas under a CBA this mechanism operates only in individual countries. Second, under the Gold Standard, money has a commodity anchor in all countries, while nowadays it is completely fiduciary. Third, under the Gold Standard, unlike the CBA, the money supply and the monetary base are close in size (Desquilbet \& Nenovsky, 2004).

In the present study, the following chain of causal links is assumed: balance of payments deficit $\rightarrow$ contraction of monetary aggregates $\rightarrow$ decline in bank lending $\rightarrow$ interest rate rise $\rightarrow$ reduction of aggregate income $\rightarrow$ decrease in total price level and change in relative price structure $\rightarrow$ real exchange rate depreciation $\rightarrow$ restoration of balance of payments equilibrium. This causal chain explains the operation of a CBA and is usually used in studies on its automatic adjustment mechanism (for example, Nenovsky \& Hristov, 1998; 2002; Nenovsky, Hristov \& Mihaylov, 2001).

There are two possible theoretical approaches to checking the functioning of the automatic mechanism of the CBA - first, aggregated testing of the whole mechanism (reduced or monetarist approach), and second, detailed testing of each unit in the causal chain (structural or Keynesian approach). The second approach is complex, requiring a detailed study of each unit and a structural model that describes the operation of the automatic mechanism of the CBA. The first approach is more appropriate for the purposes of this study because it is a special reduced method for exploring monetary issues developed by the monetarist school of economics (for example, see Andersen \& Carlson, 1970). It assumes that the entire automatic mechanism (AM) is a "black box", which includes the following elements: changes in input data (balance of payments), changes in output information (money supply) and the principle of feedback. The feedback principle can be automated, i.e. within the automatic mechanism, or discretionary, out of the automatic mechanism. In this study an empirical check of the functioning of the automatic mechanism is carried out, without the need to describe all the chains in detail, and a causal link from the balance of payments to the money supply is implied a priori.

The study of the relationship between the balance of payments and the monetary base is called a "weak" test for the existence of an automatic mechanism and the study of the relationship between balance of payments and money supply is known as a "strong" test (Nenovsky et al., 2001). Since the balance of payments - money base relationship is considered to be stronger than the balance of payments - money supply relationship, confirmation of the first link is assumed to be "weak", while confirmation of the second link is a "strong" proof of the existence of an automatic mechanism. This terminology reflects the fact that the dependence between the monetary base and the money supply is not automatic and linear, but rather a set of behavioural (most often non-linear) functions. Under 
the Gold standard, the monetary base is the largest component of money supply. In the modern world of fiduciary money, the monetary base is a small part of the whole money supply. Nowadays, deposits, different monetary and financial instruments are more important for the overall dynamics of money supply than the monetary base. Therefore, it is advisable to examine the relationship "balance of payments - money supply" through the most generalized test for the functioning of the automatic mechanism of the CBA. In this case, the "black box" of the automatic mechanism contains the behaviour of financial intermediaries, households and firms. In order for the automatic mechanism to function, two important conditions must be met: full liberalization of the economy and political and social stability (Nenovsky \& Hristov, 2002).

In this research, the "strong" test (the study of "balance of payments - money supply" relationship) is carried out. The automatic currency board mechanism (in its "strong" form) is effective only if, for a certain period of time, money supply dynamics follows the dynamics of the balance of payments, and any deviation from this parallel and synchronous movement is corrected relatively quickly and automatically (without discretionary intervention by the central bank). From an econometric point of view, this means that the two time rows need to be co-integrated and there is a mechanism for correcting the error (to restore deviations from long-term equilibrium).

It is important to specify that an automatic mechanism can only be referred to if there is a link between the balance of payments and the money supply without the presence of discretionary variables in the model. If there is a link between the balance of payments and the money supply and there are discretionary variables in the model, there is no pure functioning of the automatic mechanism, but rather adjustment by discretion (or combined adjustment by automatism and discretion) (Nenovsky et al., 2001).

The objective of this research is to identify the determinants of money supply in Bulgaria. This objective has been accomplished by fulfilling the following tasks:

- Review of theoretical and empirical research on Bulgaria's CBA (section one);

- Study of the options for monetary discretion under the Bulgarian CBA (section two);

- Empirical investigation of the determinant of money supply under the Bulgarian CBA (section three).

Studies on the automatic adjustment mechanism of the Bulgarian CBA usually employ a vector autoregression (VAR) methodology (for example, Nenovsky \& Hristov, 1998; 2002; Nenovsky et al., 2001). The VAR may be restricted (a vector error correction - VEC) or unrestricted. The restricted VAR (VEC) is used when the variables are integrated of order one and cointegrated. Otherwise, an unrestricted VAR is applied. In this research, an unrestricted VAR is employed since the variables are integrated of order zero (see Tables 1 and 2).

\section{Literature review}

Bulgaria's CBA is heavily debated in economic literature (Avramov, 1999; Carlson \& Valev, 2001; Chobanov \& Nenovsky, 2004; Desquilbet \& Nenovsky, 2004; Dobrev, 1999; Fabris \& Rodic, 2013; Hardouvelis \& Monokrousos, 2009; Hristov, 2004; Ialzanov \& Nenovsky, 2001; 
Marinova, 2016; Miller, 1999; Minassian, 2018; Moheeput, 2008; Nenovsky \& Dimitrova, 2002; Nenovsky \& Hristov, 2002; Nenovsky, Hristov \& Mihaylov, 2002; Todorov, 2013). Hanke and Schuler (1991) suggested that a currency board be introduced in Bulgaria in order to achieve a convertibility of the Bulgarian lev in foreign currency. This proposal was implemented on 1 July 1997 following a severe financial crisis involving bank failures and a serious internal and external depreciation of the Bulgarian lev.

Avramov (1999) reviewed the common features of the CBAs, their internal and external vulnerability, the peculiarities of the Bulgarian $C B A$ and possible exit strategies.

Miller (1999) analysed the first two years of the functioning of the currency board in Bulgaria in terms of its organizational structure and the strengths and weaknesses characteristic of the currency boards.

Dobrev (1999) focused on the specifics of monetary policy, financial system and management of foreign exchange reserves under the conditions of the Bulgarian currency board.

lalzanov and Nenovsky (2001) discussed the advantages and disadvantages of maintaining the currency board until Bulgaria enters the Eurozone. As an alternative to the currency board, the authors offered the so-called Euroization (the introduction of the euro in Bulgaria unilaterally or on the basis of a bilateral agreement before Bulgaria's entry to the European Monetary Union).

Carlson and Valev (2001) explored the effects of change of the exchange rate regime in 1997 on the inflation expectations in Bulgaria. The authors found that the introduction of a currency board had lowered inflationary expectations, but to varying degrees for individual business agents.

Nenovsky and Hristov (2002) empirically tested the options for discretionary monetary policy under the conditions of the Bulgarian currency board, which is part of the new generation of currency boards. The authors concluded that there were such options under the Bulgarian currency board and that the automatic adjustment mechanism, characteristic of the orthodox CBAs, did not work.

Nenovsky and Dimitrova (2002) examined the sources and dynamics of inflation in Bulgaria. They found dynamic but not static Balassa-Samuelson effect. The authors concluded that the main factors of the inflation dynamics in Bulgaria under the currency board are imported inflation and temporary differences between money supply and demand for money.

Nenovsky, Hristov and Mihaylov (2002) performed a comparative and descriptive analysis of the currency boards in Bulgaria, Estonia and Lithuania. Their conclusions were that the three CBAs did not function in a similar way and differed significantly in the reasons for their introduction, their institutional design and their available macroeconomic instruments.

Hristov (2004) tried to empirically answer the question whether the flexibility of macroeconomic instruments in Bulgaria to deal with external shocks would have been greater in a classical central bank than in a currency board arrangement. Hristov concluded that conditions for an effective discretionary monetary policy of a classical central bank in Bulgaria during the period 1997-2004 did not exist for two reasons: first, the economic 
dynamics during this period was determined mainly by structural rather than by cyclical factors and second, there is no confidence of economic agents in discretionary monetary policy.

Desquilbet and Nenovsky (2004) compared the Gold Standard and the Currency Board as monetary regimes with a high degree of confidence in monetary authorities and an automatic adjustment mechanism. The authors made two important conclusions: first, the credibility of the Gold Standard was determined by endogenous factors, and in the currency board by exogenous factors, and second, asymmetries in economic adjustment are much higher in the currency board than in the Gold Standard.

Chobanov and Nenovsky (2004) analysed empirically the liquidity of the money market in Bulgaria under a currency board. The imbalances in the Bulgarian money market could not be overcome by adjusting interest rates, as in hard CBAs, but required management of government reserves in the Central Bank balance sheet. This management allows the government to pursue a discretionary monetary policy by fiscal means.

Moheeput (2008) explored the CBAs in the context of a comprehensive analysis of the problems of choosing a currency-exchange regime. The author claimed that currency boards were created for three reasons: first, to quickly deal with financial chaos, second, as part of the medium-term stability program and third, as a long-term monetary strategy. The currency board in Bulgaria was created for the first reason - as an urgent measure to overcome a severe financial crisis and a loss of confidence in the monetary authorities.

Hardouvelis and Monokrousos (2009) and Todorov (2013) explored the stability of the Bulgarian currency board. The conclusions of both studies were that the Bulgarian currency board was stable and the most likely scenario was to maintain it until Bulgaria entered the Eurozone.

Fabris and Rodic (2013) analysed the effectiveness of CBAs as fixed exchange rate regimes compared to floating exchange rates. The current account deficit, measured as a percentage of GDP, and the rate of inflation were higher in currency board countries than in countries with floating exchange rates, indicating poor performance of the currency board as a form of exchange-rate regime.

Marinova (2016) compared monetary and fiscal policy in the Eurozone and Bulgaria. The author asserted that the main risks to the stability of public finances in Bulgaria and the Euro area were political: the frequent change of governments in Bulgaria and the lack of fiscal discipline in the currency union.

According to Minassian (2018), the currency board provided financial stability, but became an obstacle to economic growth in Bulgaria. The author recommended a change of the exchange rate regime in order to stimulate the growth and convergence of the Bulgarian economy with the developed economies of the Eurozone.

The above-mentioned studies can be classified according to different criteria such as methodology, territorial scope and conclusions.

According to their methodology, the examined studies can be divided into predominantly theoretical and predominantly empirical. The theoretical element dominates in the research of Avramov (1999), Desquilbet and Nenovsky (2004), Dobrev (1999), lalzanov and Nenovsky (2001), Miller (1999), Moheeput (2008) and Nenovsky, Hristov and Mihaylov 
(2002). Mostly empirical are the investigations of Carlson and Valev (2001), Chobanov and Nenovsky (2004), Fabris and Rodic (2013), Hardouvelis and Monokrousos (2009), Hristov (2004), Marinova (2016), Minassian (2018), Nenovsky and Dimitrova (2002), Nenovsky and Hristov (2002) and Todorov (2013).

According to their territorial scope, the reviewed sources can be grouped by research on one country and research on more than one country. The first group includes the investigations of Avramov (1999), Carlson and Valev (2001), Chobanov and Nenovsky (2004), Dobrev (1999), Hardouvelis and Monokrousos (2009), Hristov (2004), lalzanov and Nenovsky (2001), Minassian (2018), Miller (1999), Nenovsky and Dimitrova (2002), Nenovsky and Hristov (2002) and Todorov (2013). The second group consists of the analyses of Desquilbet and Nenovsky (2004), Fabris and Rodic (2013), Marinova (2016), Moheeput (2008) and Nenovsky, Hristov and Mihaylov (2002).

According to their findings, the above examined sources can be divided into studies that recommend the introduction or retention of the CBAs and studies that advocate their removal. The first group includes Avramov (1999), Hardouvelis and Monokrousos (2009), Hristov (2004), lalzanov and Nenovsky (2001), Miller (1999), Nenovsky and Hristov (2002) and Todorov (2013) among others whilst the second group includes Fabris and Rodic (2013) and Minassian (2018) among others.

Four important conclusions can be drawn from the review and the systematization of literature on the currency board in Bulgaria. First, there is a balance between theory and empirics in research. Second, there is no universal optimum currency-exchange regime. The optimum exchange rate regime is determined by specific circumstances and varies by time and country. Third, while in earlier examinations the dominant view was that the currency board in Bulgaria operated successfully and had to be preserved, the number of surveys recommending a change in the currency-exchange regime of Bulgaria has increased in recent years. Fourth, in terms of the problems analysed, the methodology employed and the conclusions reached, this paper is similar but not identical to the investigations of Nenovsky and Hristov (1998), Nenovsky and Hristov (2002) and Nenovsky, Hristov and Mihaylov (2001). ${ }^{1}$

\section{Options for monetary discretion under the Bulgarian CBA}

Unlike the first generation of hard CBAs, under the second generation of soft CBAs the ability to pursue a discretionary monetary policy is maintained. Discretionary monetary policy can be classified into two types - classical (traditional) and new (specific to the CBA). The first type of monetary policy encompasses the functions inherited from central banks, and the second type derives from the specific design of the modern CBAs (Kielyte, 2002).

\subsection{Classical (traditional) monetary tools}

The traditional monetary instruments under the Bulgarian $C B A$ are two - minimum reserve requirements (MRR) and a lender of last resort (LLR). Over the entire period of existence of

\footnotetext{
${ }^{1}$ See Appendix A for Classification of the reviewed literary sources.
} 
the CBA in Bulgaria (1997-2018), the BNB never acted as a LLR and changed the size of the MRR only three times (in July 2000 from $11 \%$ to $8 \%$, in September 2007 from $8 \%$ to $12 \%$ and in December 2008 from $12 \%$ to $8 \%$ ). The important conclusion can be drawn that traditional forms of monetary discretion are rarely used under the Bulgarian CBA.

\subsection{New (specific to the Bulgarian $\mathrm{CBA}$ ) monetary instruments}

The emergence of new channels of monetary discretion under the new generation of CBAs is determined by the choice of liabilities to be backed by a reserve currency and by the extent of the cover. In the first generation of CBAs, the liabilities are at least $100 \%$ covered and the assets backing them must be issued by non-residents. Deviation from this principle in the second generation of CBAs creates opportunities for discretionary monetary policy (Kiguel, 1999).

The inclusion of the government's fiscal reserve in the CBA liabilities (covering them with international reserves) is the main channel for the transmission of monetary policy under the Bulgarian CBA. Government revenues and expenditures have a direct impact on the monetary base and hence on money supply. In addition, privatization revenues, which account for much of the foreign direct investment (FDI) flows, go directly to the government deposit in the $\mathrm{CB}$. This mechanism creates some sort of automatic sterilization of FDI flows as the CBA is legally obliged to invest its reserves in securities issued by non-residents (when privatization revenues/proceeds are not used to finance government investment). In other words, the government may, whether deliberately or not, pursue monetary discretion. Also, this mechanism destroys the automatic link between the balance of payments dynamics and the monetary base movements. Under these circumstances, money market imbalances do not disappear by adjusting the interest rate, as in the case of the hard CBA, but require government reserve management in the $\mathrm{CB}$ balance sheet. Consequently, the government is able to use discretion by integrating fiscal and monetary policy into a syncretic whole (Nenovsky \& Hristov, 1998).

It is a well-known fact in all countries that the activity of the Ministry of Finance (MF) affects the government deposit in the $C B$ and hence, liquidity. Extensive research has been done on the effect of the MF's activities on the liquidity conditions and on the CB's monetary policy. The main difference with a CBA is that as the CBA does not carry out any monetary policy operations, MF's activity creates asymmetric liquidity shocks that cannot be compensated by the CB. MF operations are the most significant source of interest rate shocks on the Bulgarian interbank market (Dobrev, 1999).

The main argument in favour of including government reserves in CBA liabilities is that free movement of capital and high capital mobility cause large fluctuations in capital flows that directly affect the monetary base and interest rates. Under these circumstances, the fiscal policy of the government (the fiscal reserve dynamics in the CB balance sheet) can offset shocks and help smooth fluctuations in the monetary base and interest rates. Moreover, it is claimed for countries with large annual debt payments that the inclusion of government reserves in liabilities and their backing with international reserves strengthens the credibility of the CBA. Consequently, such a design reduces the volatility of the monetary 
base when government reserves are affected by large payments on foreign debt. Thus, it seems theoretically possible to design fiscal operations in a way that stabilizes interest rates in case of exogenous shocks such as the change in the direction of capital flows. In the case of the Bulgarian CBA, there are no deliberately created operations to smooth the fluctuations in interest rates, which create additional uncertainty (Miller, 1999).

The BNB is divided into two departments - Issue and Banking. The balance sheet of the Issue Department, which in fact acts as a currency board, includes international reserves that serve as collateral for its liabilities. These reserves consist of, on the one hand, the banknotes and coins typical of hard CBAs and on the other hand, of the typical of the second-generation CBAs assets such as the reserves of commercial banks, government fiscal reserves and the net value expressed by the deposit of the Banking Department. The net value exists in the hard CBAs, but only in the soft CBAs does it play the role of a buffer that absorbs shocks caused by asset transactions. Besides the role of a buffer, the net value provides the opportunity to perform the LLR function (within the Banking department deposit amount) in the event of a systemic banking crisis. The BNB may lend commercial banks in BGN through the Banking Department in case of a liquidity risk affecting the stability of the banking system. These loans are granted only to solvent banks experiencing an acute need for liquidity that cannot be provided by other sources. Loans are granted only against collateral by liquid assets and for a term not exceeding 3 months.

The deposit of the Banking Department provides the link between the Issue Department and the Banking Department and reflects the relationship between the government and the CB. The relationship between the government and the IMF goes through the balance sheet of the $\mathrm{CB}$. Tranches received in the balance sheet of the Banking Department are recorded as loans from the IMF. Within 90 days of their receipt, they are transferred to the government's account, the deposit of the Banking Department decreases and the deposit of the government increases by the amount of these tranches. When the government decides not to use the IMF tranches, they remain in the deposit of the Banking Department and provide more funds for the LLR function (Avramov, 1999).

\section{Empirical analysis of the determinant of money supply under the Bulgarian CBA}

\subsection{Methodology and data}

In this study, a vector autoregression (VAR) was applied. Monthly data of the BNB for the period January 1998 - December 2018 were used. All indicators are calculated as a percentage change rate on the previous month, except for the MRR, which are given as a percentage of the deposits, and the interbank interest rate.

All variables were tested for stationarity. If it was found that they are integrated of the first order, tests were made for the optimal number of lags and co-integration of Johansen. The optimal number of lags was used in the Johansen test and later in the construction of vector autoregression. If the Johansen test demonstrated a co-integration relationship between the variables, restricted vector autoregression (restricted VAR), also known as 
Vector Error Correction (VEC), was applied. Otherwise unrestricted vector autoregression (unrestricted VAR) was used.

In the selection of the explanatory variables involved in the vector autoregression, the general characteristics of the currency boards and the specifics of the Bulgarian currency board were taken into account.

\subsection{Results}

The determinants of money supply in Bulgaria under a CBA have been identified by a vector autoregression involving the following variables: $\mathbf{M}_{\mathbf{3}}$ - money supply; $\mathbf{H}$ - monetary base; $\mathbf{B o} \mathbf{P}$ - balance of payments; $\mathbf{G}$ - government deposit on the balance sheet of the Issue Department of the Bulgarian National Bank; MRR - minimum required reserves ratio; IR - interest rate on the interbank market. The target variable is $\mathbf{M} \mathbf{3}$. All indicators (except for IR and $\mathbf{M R R}$ ) are calculated as a percentage change on the previous month. Two binary dummy variables are also included in the model: FAL accounts for the liberalization of the balance of payments financial account in January 2000, and EUM - Bulgaria's membership in the EU since January 2007.

Table 1. Group unit root tests of $\mathrm{M}_{3}$ и BoP

\begin{tabular}{|c|c|c|c|c|}
\hline Method & Statistic & Probability & $\begin{array}{c}\text { Cross- } \\
\text { sections }\end{array}$ & Observations \\
\hline \multicolumn{5}{|c|}{ Null: Unit root (assumes common unit root process) } \\
\hline Levin, Lin \& Chu t* & -24.8959 & 0.0000 & 2 & 405 \\
\hline \multicolumn{5}{|c|}{\begin{tabular}{l|l} 
& Null: Unit root (assumes individual unit root process) \\
\end{tabular}} \\
\hline Im, Pesaran and Shin W-stat & -21.0502 & 0.0000 & 2 & 405 \\
\hline ADF - Fisher Chi-square & 208.901 & 0.0000 & 2 & 405 \\
\hline PP - Fisher Chi-square & 222.665 & 0.0000 & 2 & 406 \\
\hline
\end{tabular}

Table 2. Group unit root tests of $M_{3}$, BOP, $H, G, M R R$, IR, EUM и FAL

\begin{tabular}{|l|c|r|r|r|}
\hline \multicolumn{1}{|c|}{ Method } & Statistic & Probability & $\begin{array}{c}\text { Cross- } \\
\text { sections }\end{array}$ & Observations \\
\hline Null: Unit root (assumes common unit root process) \\
\hline Levin, Lin \& Chu t* & -3.46287 & 0.0003 & 8 & 1593 \\
\hline & & & \\
\hline Null: Unit root (assumes individual unit root process) & -17.7520 & 0.0000 & 8 & 1593 \\
\hline Im, Pesaran and Shin W-stat & 338.862 & 0.0000 & 8 & 1593 \\
\hline ADF - Fisher Chi-square & 457.026 & 0.0000 & 8 & 1624 \\
\hline PP - Fisher Chi-square & & & 8 \\
\hline
\end{tabular}

Source: Prepared by the authors. 
The unit root tests (see Tables 1 and 2) of two groups of variables (group one: $\mathbf{M}_{3}$ and BoP; group two: M3, BOP, H, G, MRR, IR, EUM and FAL) indicate that the variables are stationary (integrated of order zero), which leads to the following conclusions:

-There is no long-run equilibrium neither in the first nor in the second group of variables. This means that the automatic adjustment mechanism of the Bulgarian CBA functions neither in its pure form (as a cointegration between $\mathbf{M}_{3}$ and $\mathrm{BoP}$ ), nor with elements of discretion (as a cointegration between $\mathbf{M}_{3}$, BOP, $\mathrm{H}, \mathrm{G}, \mathbf{M R R}$, IR, EUM and FAL);

- The relationship between M3, BOP, H, G, MRR, IR, EUM and FAL should be modelled by unrestricted VAR, but not by restricted VAR (vector error correction).

Table 3. Optimal lag length in the VAR model

\begin{tabular}{|c|r|r|r|r|}
\hline Number of lags & \multicolumn{1}{|c|}{ FPE } & \multicolumn{1}{c|}{ AIC } & \multicolumn{1}{c|}{ SC } & \multicolumn{1}{c|}{ HQ } \\
\hline 0 & 12.94415 & 25.26366 & 25.39746 & 25.31783 \\
\hline 1 & 0.000872 & 15.65738 & $16.86158 *$ & $16.14490 *$ \\
\hline 2 & 0.001133 & 15.91636 & 18.19097 & 16.83724 \\
\hline 3 & 0.001527 & 16.20768 & 19.55269 & 17.56190 \\
\hline 4 & 0.001800 & 16.35726 & 20.77268 & 18.14484 \\
\hline 5 & 0.002159 & 16.51489 & 22.00071 & 18.73581 \\
\hline 6 & 0.001317 & 15.98412 & 22.54034 & 18.63839 \\
\hline 7 & 0.000630 & 15.19469 & 22.82132 & 18.28231 \\
\hline 8 & $0.000570 *$ & $15.02476 *$ & 23.72180 & 18.54574 \\
\hline
\end{tabular}

* Shows the optimal number of lags according to the respective criterion Source: Prepared by the authors.

The test for the optimal number of lags in the vector autoregression shows that according to the Schwarz and Hannan-Quinn criteria this number is one lag (see Table 3). The vector autoregression is estimated with one lag.

The equation for the target variable in the VAR model $\mathbf{M}_{3}$ after the step-by step removal of statistically insignificant variables is:

(1) $M_{3}=1.43-0.16 * M_{3}(-1)+0.04 * G(-1)+0.22 * I R(-1)-0.80 * E U M(-1)$

The results from the estimation of Equation (1) are shown in Table 4.

Table 4. Results from the estimation of Equation (1)

\begin{tabular}{|c|r|r|r|r|}
\hline Variable & \multicolumn{1}{|c|}{ Coefficient } & \multicolumn{1}{|c|}{ Standard error } & \multicolumn{1}{c|}{ t-Statistic } & \multicolumn{1}{c|}{ Probability } \\
\hline C & 1.426484 & 0.334333 & 4.266653 & 0.0000 \\
\hline M3(-1) & -0.159794 & 0.068559 & -2.330731 & 0.0208 \\
\hline$G(-1)$ & 0.042438 & 0.013423 & 3.161513 & 0.0018 \\
\hline IR(-1) & 0.217588 & 0.098212 & 2.215495 & 0.0279 \\
\hline EUM(-1) & -0.796475 & 0.325862 & -2.444210 & 0.0154 \\
\hline
\end{tabular}

Source: Prepared by the authors.

The percentage rate of change of money supply is influenced by the lagged values of money supply, government deposit, interbank interest rate and the EU membership. The only statistically significant variable, which provides an opportunity for a discretionary 
monetary policy, is the deposit of government in the balance sheet of the Issue department of the BNB.

The value of the coefficient of determination (R-squared $=0.13$ ) indicates that $13 \%$ of the variation of money supply in Bulgaria can be explained by changes in the independent variables in Equation (1). The probability of the F-statistic $(0,00)$ shows that the alternative hypothesis of adequacy of the model used is confirmed. It should be made clear that this does not mean that the model is the best possible but simply adequately reflects the relationship between the dependent and the independent variables.

The CUSUM test results imply that Equation (1) is dynamically stable (see Figure 1), as the actual CUSUM values are within the confidence interval at the $5 \%$ significance level. The Ramsey RESET test results (probability of the F-statistic 0.7581) suggest acceptance of the null hypothesis of a lack of errors in the specification of Equation (1).

Figure 1. CUSUM test for dynamic stability of Equation (1)

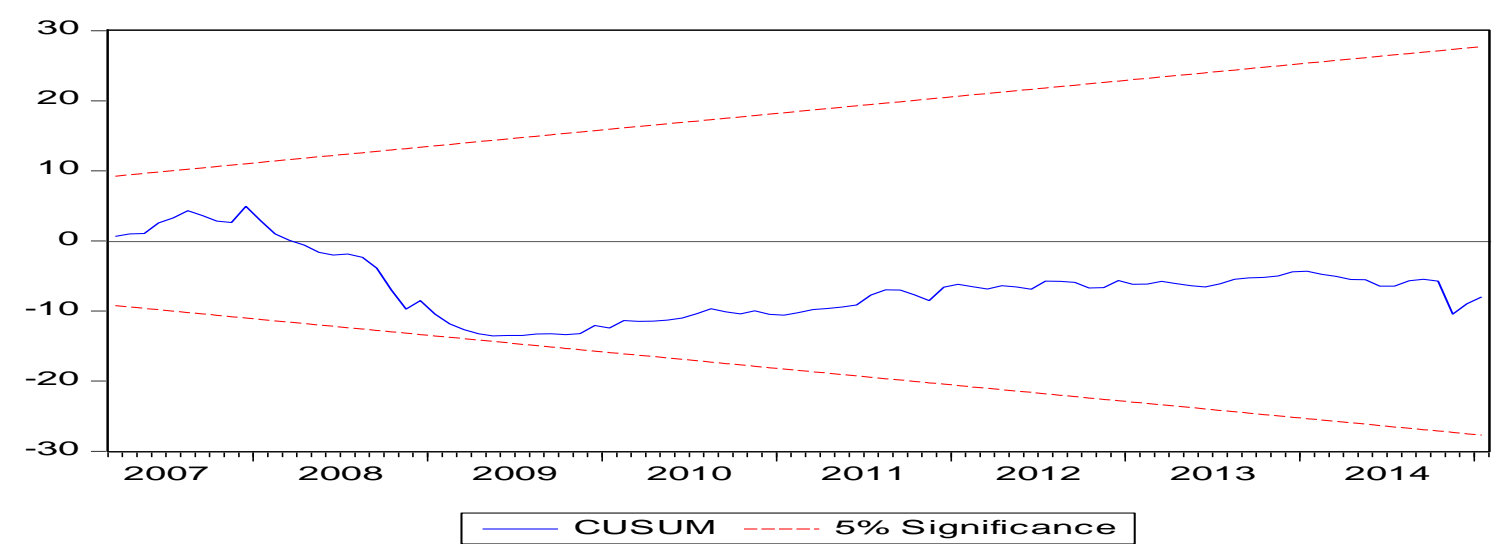

Source: Prepared by the authors.

\section{Conclusion}

Empirical results in this study indicate that the automatic adjustment mechanism of the Bulgarian CBA operates neither in its pure form (cointegration between $\mathbf{M}_{3}$ and BoP), nor with discretionary elements (cointegration between M3, BOP, H, G, MRR, IR, EUM and FAL). Money supply is affected by its own past values and the past values of the government deposit, interbank interest rate and EU membership. Discretionary impact on money supply under the Bulgarian CBA can be achieved by changing the deposit of government in the balance sheet of the Issue department of the BNB. There is no evidence of a statistically significant effect of the MRR on money supply.

It may be inferred that money supply in Bulgaria under a CBA is more discretion-driven than automatically determined.

The comparison of this research with other studies on the same or similar topic such as Nenovsky and Hristov (1998), Nenovsky and Hristov (2002) and Nenovsky, Hristov and Mihaylov (2001) leads to the following inferences: 
- By the methodology employed (VAR), the present study resembles the investigations of Nenovsky and Hristov (1998) and Nenovsky, Hristov and Mihaylov (2001) and differs from the research of Nenovsky and Hristov (2002), which uses a cointegration analysis/error correction;

- All four studies agree that there is evidence of a statistically significant impact of the changes in the government deposit in the Bulgarian National Bank on monetary base/money supply;

- All four investigations concur that the automatic adjustment mechanism of the Bulgarian $C B A$ does not function in its pure form (as a cointegration between the balance of payments and monetary base/money supply);

- According to Nenovsky and Hristov (2002) and Nenovsky, Hristov and Mihaylov (2001), the automatic adjustment mechanism of the Bulgarian CBA works with elements of discretion (when the deposit of government is included in the model). However, the present study found no proof of cointegration between the balance of payments, money supply and the government deposit).

The limitations of this study are three:

1.The determinants of monetary base in Bulgaria have not been empirically investigated;

2.The hypothesis of the existence of a liquidity effect under the Bulgarian CBA has not been tested;

3.The relationship between the balance of payments and monetary base has not been explored.

The limitations of this study can be overcome by future research. The authors intend to fill the gaps in this study by identifying the determinants of monetary base in Bulgaria, testing the hypothesis of liquidity effect and examining the relationship between the balance of payments and monetary base.

\section{References}

Andersen, L. C. \& Carlson, K. M. (1970). A monetarist model for economic stabilization. Federal Reserve Bank of St. Louis Review, 1-19.

Avramov, R. (1999). The role of a currency board in financial crises: The case of Bulgaria. Discussion Paper dp/6/1999. Bulgarian National Bank.

Carlson, J. A. \& Valev, N. T. (2001). Credibility of a new monetary regime: The currency board in Bulgaria. Journal of Monetary Economics, 47(3), 581-594. DOI: 10.1016/S0304-3932(01)00057-5

Chobanov, P. \& Nenovsky, N. (2004). Money market liquidity under currency board - Empirical investigations for Bulgaria. Working Paper No. 693. Michigan: The William Davidson Institute, University of Michigan.

Desquilbet, J. B. \& Nenovsky, N. (2004). Credibility and adjustment: Gold standards versus currency boards. Working Paper No. 692. Michigan: The William Davidson Institute, University of Michigan.

Dobrev, D. (1999). The currency board in Bulgaria: Design, peculiarities and management of foreign exchange cover. Discussion papers ZDB-ID 2169813-2, Vol. 9. Sofia: Bulgarian National Bank.

Fabris, N. \& Rodic, G. (2013). The efficiency of the currency board arrangement. Journal of Central Banking Theory and Practice, 1, 157-176. 
Hanke, S. \& Schuler, K. (1991). Teeth for the Bulgarian lev: A currency board solution. Washington, D.C.: International Freedom Foundation.

Hardouvelis, G. A. \& Monokrousos, P. (2009). Is Bulgaria's currency board sustainable? Economy \& Markets, Eurobank Research, 4(7), 2-26.

Hristov, K. (2004). The currency board: The only game in town. Discussion Paper 40/2004. Sofia: Bulgaria National Bank.

Ialzanov, D. \& Nenovsky, N. (2001). The currency board and Bulgaria's accession to the European monetary union. Kyoto University Economic Review, 70(1/2), 31-48. DOI: 10.11179/ker1926.70.31

Kielyte, J. (2002). Exchange rate arrangements in the run-up to the EMU: Some experience in currency board countries. Economic and Econometrics Research Paper Series 2002.01.

Kiguel, M. A. (1999). The Argentine currency board. CEMA Working Papers No. 152, Universidad del CEMA.

Marinova, T. (2016). Comparative study on monetary and fiscal policy in the Eurozone and Bulgaria. Economic Alternatives, (3), 367-378.

Miller, J. B. (1999). The currency board in Bulgaria: The first two years. Discussion Papers 11/1999. Sofia: Bulgarian National Bank.

Minassian, G. (2018). Two decades of currency board in Bulgaria: How much more? Bulgaria in Europe: Lagging behind or catching up. Strategies for catch-up development (pp. 60-98). Sofia: Institute for New Economic Thought.

Moheeput, A. (2008). Issues on the choice of exchange rate regimes and currency boards - An analytical survey. Warwick Economic Research Papers No. 855. Coventry: University of Warwick, Department of Economics.

Nenovsky, N. \& Dimitrova, K. (2002). Dual inflation under the currency board: The challenges of Bulgarian EU accession. Working Papers Series No. 487. Michigan: The William Davidson Institute, University of Michigan.

Nenovsky, N. \& Hristov, K. (1998). Financial repression and credit rationing under currency board arrangement for Bulgaria. Discussion Papers 2/1998. Sofia: Bulgarian National Bank.

Nenovsky, N. \& Hristov, K. (2002). The new currency boards and discretion: Empirical evidence from Bulgaria. Economic Systems, 26(1), 55-72. DOI: 10.1016/So939-3625(02)00005-5

Nenovsky, N., Hristov, K. \& Mihaylov, M. (2001). A simple test of currency board automatic mechanism in Bulgaria, Estonia and Lithuania. Journal des Economistes et des Etudes Humaines, XI(4), 575616.

Nenovsky, N., Hristov, K. \& Mihaylov, M. (2002). Comparing the institutional and organizational design of currency boards in transition countries. Eastern European Economics, 40(1), 6-35.

Todorov, I. (2013). The Bulgarian currency board arrangement in the context of the future membership of Bulgaria in the euro area. Ikonomicheski i sotsialni alternativi, 3, 112-124. 


\section{APPENDIX A}

Table A. Classification of the reviewed literary sources

\begin{tabular}{|c|c|c|c|}
\hline Literary source & Methodology & Territorial scope & Conclusions \\
\hline Avramov (1999) & $\begin{array}{l}\text { Descriptive and trend } \\
\text { analysis of the Bulgarian } \\
\text { CBA }\end{array}$ & Bulgaria & $\begin{array}{l}\text { The introduction of the CBA in } \\
\text { Bulgaria in } 1997 \text { was crucial to } \\
\text { overcoming the economic and } \\
\text { financial crisis of } 1996-1997 \text {. }\end{array}$ \\
\hline Carlson \& Valev (2001) & $\begin{array}{|lr|}\text { Survey about the impact } \\
\text { of the CBA introduction } \\
\text { on } & \text { inflation } \\
\text { expectations } & \text { of } \\
\text { different } & \text { economic } \\
\text { agents } & \\
\end{array}$ & Bulgaria & $\begin{array}{l}\text { Expected inflation is lowered by the } \\
\text { prospect of a currency board but to } \\
\text { a different degree for different } \\
\text { agents. }\end{array}$ \\
\hline $\begin{array}{|lll|}\begin{array}{l}\text { Chobanov \& } \\
(2004)\end{array} & & \\
& & \\
& & \\
& & \\
\end{array}$ & $\begin{array}{l}\text { GARCH analysis of the } \\
\text { volume and interest } \\
\text { rate of unsecured } \\
\text { overnight deposits at } \\
\text { Bulgarian interbank } \\
\text { market }\end{array}$ & Bulgaria & $\begin{array}{l}\text { Under the Bulgarian CBA, money } \\
\text { market disequilibria do not } \\
\text { disappear with interest rate } \\
\text { adjustment, as they do under an } \\
\text { orthodox currency board, but } \\
\text { rather require a management of } \\
\text { government reserves in the central } \\
\text { bank's balance sheet. }\end{array}$ \\
\hline \begin{tabular}{|l} 
Desquilbet \& \\
$(2004)$
\end{tabular} & $\begin{array}{l}\text { Comparative analysis of } \\
\text { the Gold Standard and } \\
\text { the CBAs }\end{array}$ & $\begin{array}{l}\text { Countries, which } \\
\text { participated in the } \\
\text { system of the Gold } \\
\text { Standard and countries } \\
\text { with a CBA }\end{array}$ & $\begin{array}{l}\text { The credibility of the Gold Standard } \\
\text { is determined by endogenous, and } \\
\text { of a currency board by exogenous } \\
\text { factors. Asymmetries in economic } \\
\text { adjustment are much higher in a } \\
\text { currency board than in the Gold } \\
\text { Standard. }\end{array}$ \\
\hline Dobrev (1999) & $\begin{array}{l}\text { Comparative analysis of } \\
\text { the Bulgarian CBA with } \\
\text { orthodox CBAs }\end{array}$ & Bulgaria & $\begin{array}{l}\text { The Bulgarian CBA possesses the } \\
\text { basic features of an orthodox CBA, } \\
\text { but its design is more flexible } \\
\text { because of the financial crisis } \\
\text { before its introduction. }\end{array}$ \\
\hline Fabris \& Rodic (2013) & $\begin{array}{l}\text { Comparative analysis of } \\
\text { economic performance } \\
\text { of countries with fixed } \\
\text { and flexible exchange } \\
\text { rates }\end{array}$ & $\begin{array}{l}\text { Countries with different } \\
\text { exchange rate regimes }\end{array}$ & $\begin{array}{l}\text { Countries with flexible exchange } \\
\text { rates have lower inflation rates and } \\
\text { current account deficits than } \\
\text { countries with CBAs. }\end{array}$ \\
\hline Hanke \& Schuler (1991) & $\begin{array}{l}\text { Comparative analysis of } \\
\text { CBAs and central banks }\end{array}$ & $\begin{array}{l}\text { Countries with central } \\
\text { banks and countries } \\
\text { with CBAs }\end{array}$ & $\begin{array}{l}\text { CBAs are an efficient method for } \\
\text { restoring public confidence in } \\
\text { monetary authorities and for } \\
\text { overcoming financial crises. }\end{array}$ \\
\hline $\begin{array}{l}\text { Hardouvelis } \\
\text { Monokrousos (2009) }\end{array}$ & $\begin{array}{l}\text { Cross-country } \\
\text { comparison }\end{array}$ & $\begin{array}{l}\text { Bulgaria and the Baltic } \\
\text { states }\end{array}$ & $\begin{array}{l}\text { Bulgaria's CBA is sustainable and } \\
\text { should be maintained till adoption } \\
\text { of the Euro. }\end{array}$ \\
\hline Hristov (2004) & $\begin{array}{l}\text { Comparison of } \\
\text { monetary conditions } \\
\text { under Taylor rule and } \\
\text { McCallum rule based } \\
\text { policies with monetary } \\
\text { conditions under a CBA } \\
\end{array}$ & Bulgaria & $\begin{array}{l}\text { Monetary conditions in the } \\
\text { economy would have been more } \\
\text { restrictive if Bulgaria followed } \\
\text { Taylor rule and McCallum rule } \\
\text { based policies than under a CBA. }\end{array}$ \\
\hline Ialzanov \& Nenovsky (2001) & $\begin{array}{l}\text { Comparison of different } \\
\text { exchange rate strategy } \\
\text { options for Bulgaria }\end{array}$ & Bulgaria & $\begin{array}{l}\text { It is advisable that Bulgaria keep the } \\
\text { CBA till Euro area entry. }\end{array}$ \\
\hline Kielyte (2002) & $\begin{array}{l}\text { Comparative analysis of } \\
\text { the CBAs in Bulgaria, } \\
\text { Estonia and Lithuania }\end{array}$ & $\begin{array}{l}\text { Bulgaria, Estonia and } \\
\text { Lithuania }\end{array}$ & $\begin{array}{l}\text { The CBAs are a good exchange-rate } \\
\text { strategy for small open economies }\end{array}$ \\
\hline
\end{tabular}




\begin{tabular}{|c|c|c|c|}
\hline & & & $\begin{array}{l}\text { like Bulgaria, Estonia and Lithuania } \\
\text { till Euro adoption. }\end{array}$ \\
\hline Kiguel (1999) & $\begin{array}{llr}\text { Descriptive } & \text { and } & \text { trend } \\
\text { analysis } & \text { of } & \text { the } \\
\text { Argentine CBA } & \end{array}$ & Argentina & $\begin{array}{l}\text { A strict exchange rate rule can be a } \\
\text { strong alternative to other } \\
\text { exchange rate regimes to ensure } \\
\text { macroeconomic stability in a } \\
\text { globalized world with highly } \\
\text { integrated capital markets. }\end{array}$ \\
\hline Marinova (2016) & $\begin{array}{l}\text { Comparative analysis of } \\
\text { monetary and fiscal } \\
\text { policies in the Euro area } \\
\text { and Bulgaria }\end{array}$ & & $\begin{array}{l}\text { Current challenges to monetary } \\
\text { and fiscal policy in the Eurozone } \\
\text { and Bulgaria are mostly due to the } \\
\text { institutional basis and its } \\
\text { implementation. }\end{array}$ \\
\hline Miller (1999) & $\begin{array}{l}\text { Descriptive and trend } \\
\text { analysis of the Bulgarian } \\
\text { CBA }\end{array}$ & Bulgaria & $\begin{array}{l}\text { The currency board has brought } \\
\text { stability to the economy. The next } \\
\text { stage will test whether these gains } \\
\text { can be consolidated and longer- } \\
\text { term growth can be achieved. }\end{array}$ \\
\hline Minassian (2018) & $\begin{array}{l}\text { Comparative, } \\
\text { descriptive and trend } \\
\text { analysis of } \\
\text { macroeconomic } \\
\text { conditions and } \\
\text { developments in the } \\
\text { new EU member states } \\
\text { from Central and } \\
\text { Eastern Europe }\end{array}$ & $\begin{array}{l}\text { New EU member st } \\
\text { from Central } \\
\text { Eastern Europe }\end{array}$ & $\begin{array}{l}\text { The Bulgarian CBA maintains } \\
\text { financial stability but hampers } \\
\text { economic growth. }\end{array}$ \\
\hline Moheeput (2008) & $\begin{array}{l}\text { Comparative analysis of } \\
\text { fixed and floating } \\
\text { exchange rate regimes }\end{array}$ & $\begin{array}{l}\text { Countries with fixed } \\
\text { floating exchange } \\
\text { regimes }\end{array}$ & $\begin{array}{l}\text { For economies with a short-term } \\
\text { horizon, currency boards deliver } \\
\text { fast results. For economies with a } \\
\text { medium and long-term perspective, } \\
\text { institutional factors must be } \\
\text { present as pre-requisites for } \\
\text { currency boards to work. }\end{array}$ \\
\hline \begin{tabular}{lll|} 
Nenovsky \& \\
$(2002)$
\end{tabular} & $\begin{array}{l}\text { OLS regression analysis } \\
\text { of the } \quad \text { Balassa- } \\
\text { Samuelson effect in } \\
\text { Bulgaria }\end{array}$ & Bulgaria & $\begin{array}{l}\text { There is dynamic but not static } \\
\text { Balassa-Samuelson effect in } \\
\text { Bulgaria. The main factors of the } \\
\text { inflation dynamics in Bulgaria under } \\
\text { the currency board are imported } \\
\text { inflation and temporary differences } \\
\text { between money supply and } \\
\text { demand for money. }\end{array}$ \\
\hline Nenovsky \& Hristov (1998) & $\begin{array}{l}\text { VAR analysis of the } \\
\text { INFLUENCE } \\
\text { GOVERNMENT DEPOSIT } \\
\text { ON COMMERCIAL BANK } \\
\text { EXCESS RESERVES, } \\
\text { RESERVE MONEY AND } \\
\text { MONEY SUPPLY }\end{array}$ & Bulgaria & $\begin{array}{l}\text { Possibilities exist for the currency } \\
\text { board operation to be improved. } \\
\text { These possibilities are related to } \\
\text { the removal of the government } \\
\text { deposit from the liabilities of the } \\
\text { CBA, to the elimination of the } \\
\text { minimum reserve requirements } \\
\text { and to abolition of the base interest } \\
\text { rate. }\end{array}$ \\
\hline Nenovsky \& Hristov (2002) & $\begin{array}{l}\text { Cointegration analysis } \\
\text { (VEC) of the automatic } \\
\text { adjustment mechanism } \\
\text { of the Bulgarian CBA }\end{array}$ & Bulgaria & $\begin{array}{l}\text { The automatic adjustment } \\
\text { mechanism of the orthodox CB } \\
\text { does not work, for reserve money } \\
\text { supply dynamics does not follow } \\
\text { BOPs dynamics. Nevertheless, } \\
\text { there exists a long-run } \\
\text { cointegration relation between the } \\
\text { two variables if we include }\end{array}$ \\
\hline
\end{tabular}




\begin{tabular}{|c|c|c|c|}
\hline & & & $\begin{array}{l}\text { government fiscal reserves as an } \\
\text { outside variable in the VEC. We can } \\
\text { speak of an "adjustment } \\
\text { mechanism through discretion } \\
\text { conscious or unconscious". } \\
\text { However, this type of adjustment } \\
\text { cannot be called a pure automatic } \\
\text { mechanism. }\end{array}$ \\
\hline $\begin{array}{l}\text { Nenovsky, Hristov } \\
\text { Mihaylov (2001) }\end{array}$ & $\begin{array}{l}\text { \& VAR and VEC analysis of } \\
\text { the automatic } \\
\text { adjustment and } \\
\text { mechanisms a } \\
\text { liquidity effects of the } \\
\text { CBAs in Bulgaria, } \\
\text { Estonia and Lithuania }\end{array}$ & $\begin{array}{l}\text { Bulgaria, Estonia } \\
\text { Lithuania }\end{array}$ & $\begin{array}{l}\text { and The automatic mechanism } \\
\text { operates in Estonia and Lithuania } \\
\text { only in its weak test form (between } \\
\text { the balance of payments and } \\
\text { reserve money). In Bulgaria the } \\
\text { operation of the automatic } \\
\text { mechanism is more or less reduced } \\
\text { to "adjustment through } \\
\text { discretion." Government deposit } \\
\text { plays a key role in adjustment to } \\
\text { balance of payment shocks in a } \\
\text { case of Bulgarian currency board. } \\
\text { Empirical tests confirm the } \\
\text { assumption that liquidity effect is } \\
\text { present both in Bulgaria and } \\
\text { Lithuania. }\end{array}$ \\
\hline $\begin{array}{l}\text { Nenovsky, Hristov } \\
\text { Mihaylov (2002) }\end{array}$ & $\begin{array}{l}\text { Comparative and } \\
\text { descriptive analysis of } \\
\text { the CBAs in Bulgaria, } \\
\text { Estonia and Lithuania }\end{array}$ & $\begin{array}{l}\text { Bulgaria, Estonia } \\
\text { Lithuania }\end{array}$ & $\begin{array}{l}\text { and The comparison of currency board } \\
\text { operation in the three countries } \\
\text { reveals significant differences in } \\
\text { the historical background of } \\
\text { currency board adoption, } \\
\text { institutional design, and overall } \\
\text { macroeconomic framework. This } \\
\text { observation does not fit completely } \\
\text { with the generally accepted view } \\
\text { that currency boards in the three } \\
\text { transition economies function in a } \\
\text { similar pattern and that the } \\
\text { differences among them are } \\
\text { insignificant. }\end{array}$ \\
\hline Todorov (2013) & $\begin{array}{l}\text { Descriptive and trend } \\
\text { analysis of the Bulgarian } \\
\text { CBA }\end{array}$ & Bulgaria & $\begin{array}{l}\text { Bulgaria's CBA is sustainable and } \\
\text { should be maintained till adoption } \\
\text { of the Euro. }\end{array}$ \\
\hline
\end{tabular}

Source: Prepared by the authors.

IVAN TODOROV holds a PhD in Finance and is chief assistant professor at the Faculty of Economics of the South-West University "Neofit Rilski" in Blagoevgrad. His research areas are Macroeconomics, Public Finance and International Finance. Institutional address: South-West University "Neofit Rilski”, Faculty of Economics, Department of Finance and Accounting, 66 Ivan Mihaylov Street, 2700 Blagoevgrad, Bulgaria, email: ivank.todorov@swu.bg

STOYAN TANCHEV holds a PhD in Finance and is an assistant professor at the Faculty of Economics of the South-West University "Neofit Rilski" in Blagoevgrad. His research is in the field of taxes and tax systems. Institutional address: South-West University "Neofit Rilski", Faculty of Economics, Department of Finance and Accounting, 66 Ivan Mihaylov Street, 2700 Blagoevgrad, Bulgaria, email: saneto@swu.bg 
PETAR YURUKOV is a PhD candidate at the Faculty of Economics of the South-West University "Neofit Rilski" in Blagoevgrad. His doctoral thesis is related to the impact of the currency board arrangement on the economic growth of Bulgaria. Institutional address: South-West University "Neofit Rilski", Faculty of Economics, Department of Finance and Accounting, 66 Ivan Mihaylov Street, 2700 Blagoevgrad, Bulgaria, email: petaryurukovofficial@gmail.com

Submitted on January 17, 2019

Acepted on April 9, 2019 